\title{
Green marketing - A Theoretical study of opportunities and threats in the context of Indian market
}

\author{
Anjali Yadav ${ }^{*}$, Urvashi Sharma² \\ ${ }^{1}$ PH.D Scholar, ${ }^{2}$ Assistant Professor, ${ }^{1,2}$ FCBS Manav Rachna International Institute of Research and Studies, Faridabad, Haryana, India \\ *Corresponding Author: Anjali Yadav \\ Email: anjaliyadav3107@gmail.com
}

\begin{abstract}
Green becomes the buzz around the globe. This leads to the increased awareness on the topic of ecological threats and affecting the lives of everyone. Individuals are now approaching toward the green life which increases the demand of green players in the market. This is been observed that many business associations have started identifying the need of greening and started implemented the green marketing strategies in the businesses. In this era of globalization and competitive environment green marketing works as a wonder. It is helpful in developing the image of organization, attracting more consumers, avoiding the interference of government and various environment protection NGO's and helpful in remaining the business for a long run. Instead of numerous benefits the green marketing is still in its stage of infancy in India. Through this paper an attempt is made to introduce the concept of green marketing and highlights the benefits of adopting green marketing strategies in the business. This paper also identifies the various challenges appearing in the way of implementing green marketing concept. It also examines the present scenario of green marketing in Indian market.
\end{abstract}

Keywords: Green marketing, Globalization, Ecological, Green life.

\section{Introduction}

Sustainability becomes the talk of the globe and people are becoming more aware about the concept not locally but globally. In this era of globalization there is a need of paradigm shift in the mindset of producers and consumers about their role in attaining sustainability. Marketing is the process of identifying consumers need and preference, developing products according to the need and preferences. And offer in the market with reasonable rates. Marketing is basically the process of creating, communicating, and exchanging product and services with the consumers, collaborators, and society at large. Green marketing includes doing all the marketing activities keeping green or sustainable vision in mind.

The American Marketing Association (AMA) defines green marketing as the products that are environment friendly made which includes the changes in the process of production, packaging and labelling, green advertisement practices and creating awareness among the consumers and other producers in the market. According to Polonsky (1994) green marketing includes all the process of identifying and formulating strategies to fulfill the demands of consumers with the minimum impact on natural environment.

\section{4p's of green marketing mix}

1. Product: A product is a bundle of satisfaction. A green product is a product that is designed with the sustainability, which is less energy consuming, spares water, vitality, no animal testing, no toxic materials, and no hazardous impact on environment and human health. McDonald's is a very good example, changes their polystyrene clamshells to wax paper.

2. Price: Most of the studies found that a consumer can pay premium amount if sufficient benefits are associated with the products. Benefits in terms of appearance, functional differentiation, taste, design etc. Natural protection itself a great reward but the consumers will only pay premium after knowing the benefits. So, a producer must educate their consumers about the concept of sustainability and their benefits.

3. Place: Availability of products makes a significant effect on the consumers as no consumer is willing to put extra efforts on buying green products. Therefore, the product should be made available at the right time and at the right place. An organization can simply avail the benefits of advertisement to make consumers aware about the environment protection and the availability of products. It can be done by less or more use of visual presentation, using recycled products for highlighting sustainability, and in store promotional techniques.

4. Promotion: Effective promotion is always a key to success. Product and services that are promoted to target market through sales promotion, advertisement, direct marketing should be promoting considering environmental credibility. For instance, majority of banking sector are using electronic medium for providing statements and other information's. IndusInd bank removes the use of counterfoil from their atm's and operate through electronic medium. The initiative of "DO BUCKET PAANI ROZ BACHANA" by Surf excel for promoting the idea of water conservation.

\section{Green product and characteristics}

There is no such definition of green or green products. A green product is a product which is designed in a sustainable manner to minimize the impact on environment during whole life and even after that. We define green product as a product which creates a less impact on the environment and human health compared to traditional product (Sumit Narula 2016). 
Basic characteristics of green products:

1. Energy efficient.

2. Low maintenance required.

3. Spares water.

4. No toxic chemical.

5. Product with no animal testing.

6. Less packaging.

7. Naturally grown ingredient.

8. Recycled and reusable benefits.

9. Less pollution on environment.

10. No hazardous impact on human health.

\section{Green marketing opportunities}

1. First mover advantage - As there is a shift in the demand of consumers, many firms are changing themselves according to the demands to avail the opportunity of environmentally responsible organization's as an alternative in the market. McDonald's changed their packaging paper of clamshell with the waxed paper due to increased concerns of consumers toward environment protection.

2. To avoid governmental intervention - Government is concerned for the protection of consumers and society from the exploitation of marketing activities of firms. Government keeps an eye on the organizational performances and established regulations related to the sustainability in the marketing to protect the consumer from hazardous waste of firms.

3. Helpful in remining in the business - There is a cutthroat competition in the market at global level. To remain in the business the firms should adopt the environmental behavior. Sometimes the attempts made by some organizations caused pressure on others in the entire industry to adopt ecofriendly measures if they desire to remain in the business. In 1999's the driftnets on the sea were responsible for the drowning of app. 100,000 dolphins per year. Due to which the canned tuna manufacturer companies such as Chicken of the sea, Bumble bee, and Starkist seafood stopped the purchase of tuna that are caught in driftnets and started buying "dolphin safe" tuna which leads to stop the usage of driftnets by the tuna manufacturers in the sea.

4. Fulfilling social responsibility - Business is the integral part of the society that intakes almost all the resources from the society which makes it liable for fulfilling the responsibility arises towards the society. Many big brands are now performing considering the concept of environmental protection. ITC fulfilling their CSR through generating livelihood and environment capitals. ITC implemented the principles of sustainability into the various stages including procurement of raw materials, production, transportation of production and waste management.

5. Management of waste - Management of waste produced by the organizations can be dully benefitted. It is helpful in reducing the amount of hazardous waste and helpful in saving cost. Coca Cola Company invested a large amount of money in recycling activities and in packaging modification. Coca cola used $40 \%$ of recycled bottles every year and planning to increase 100\% recycled bottles by 2025 .

\section{Objectives of the study}

1. To highlight the concept of green marketing.

2. To find the possible difficulties appearing in the way of green marketing.

3. To understand the opportunities associated with the green marketing.

4. To analyze the cases of green marketing in India.

\section{Literature review}

MacDaniel S.W \& Rylander (1993) stated in their article "strategic green marketing", that the future of business is taking shape with the key strategies of green marketing.

Rosenberger, Polansky \& Ottman (1998), mentioned in their research article entitles "Developing Green Products: Learning from Stakeholders" based on Australian and Us market. The study shows the relationship between development of green products and attitude and perception of stakeholders towards them. The finding of the paper also suggests that the stakeholders with "high" influencing capability should be involved in the process of green product development process.

Yazdanifard (2011), examined that green marketing strategies are not only the tool for environmental protection but also as a strategy of marketing for attracting more consumers and helpful in building image.

Chan (2013), revealed in his paper that there are multiple green marketing practices such as sustainability in procurement of raw material, green production, eco labelling of products, recycling, green transportation and green pricing of products.

S. William John (2015), stated that greening the consumers are depending upon the marketer by identifying the strategies to make consumer aware about the green products and its non-hazardous impact on human health and animals.

Sangeetha (2015) stated that green marketing strategies integrates the sustainable approach in all spheres of the organizational performance from product planning to consumer handling. To remain in the competitive environment companies will have to look green marketing as an opportunity through implementing environment friendly practices as waste management, water conservation, air pollution measures and standardization of eco products.

Woung Fui Yeng \& Rashid Yazdanifard (2015), examined that the importance of green marketing is identified 
by many organizations and acknowledged the value of green products. Study also reveals that green marketing can be used as a tool for making profit maximization.

Sumit Narula (2016). Acknowledged in his paper that green marketing is an opportunity to choose globally. It will bring some intense changes in the realms of organizations and all nations are required to make strict policies and principles to make the world safe from contamination.

Jayadatta (2017), found in their study that a marketer should make their consumers understand about the need and benefits of green products and consumer will pay premium for greener environment.

Jayadutta. S \& Sayed Amen Ahmed (2017), highlighted the importance of gren marketing and staed that green marketing is still a new concept and consumers need to be educated. Organizations should adopt green marketing campaign to make a change in consumers buying behavior and motivate them to buy green products even with premium cost.

Nagender Kumar Sharma (2019), deciphered that eco labels are the most efficient tool for green marketing. Eco labels provides the significant information about the green characteristics of a product to the consumer and helpful in persuading to buy the product as benefits to consumer and environmental protection are associated with the products.

\section{Threats in green marketing}

1. Need for standardization and green laws - according to various studies it is found that the marketing message by various organizations and campaigns by various organizations are entirely true by only $5 \%$ (J. Bharanitharan) because there is a lack of proper standardization and the tools for checking the authenticity of the green claims. Government should take effective measures in formulating such standards for green production and green laws (Moloy Ghoshal 2011) for effective authenticity of green products.

2. Green, a new concept in India - green marketing is a new concept in Indian market educated and urban people are aware about the importance of environment protection (Sumit Narula 2016) but still work needs to be done to make aware the consumers about the ecofriendly practices and products through providing green education. Patanjali Ayurveda limited brings a change in the mindset of Indian consumers and consumers started understanding the importance and started appreciating natural products.

3. Green myopia - green myopia is a narrow productoriented marketing strategy, producers are highlighting the characteristics of a green products instead of the benefits associated for the consumers. There are numerous green products available in the market but fails due to not marketed with the green benefits to the consumers. The consumer however wants the marketer to enlighten the green benefits to the consumers, if they use green products (Ottman 2006).

4. Premium cost added to product - production of green products requires more cost as compared to non-green products therefore premium cost is added to the products. A producer should be aware before charging the premium cost that the consumer will be able to understand the importance of green product and feel worthy of buying the products. Whirlpool launched the CFC free refrigerators in the market, but the consumers did not want to buy the product with the premium cost because consumers did not know about the CFC and its impact on environment. That teaches a hard lesson to whirlpool.

5. Green marketing is beneficial in long run - since greening is the new concept in the market requires its own time for acceptance. Marketer should see the sustainability as a long term investment opportunity. The practices adopted by organizations are beneficial only in a long run.

\section{Research methodology}

In the present study research methodology adopted is based upon the data gathered from secondary data through newspapers, magazines, research articles, google scholar etc. this study is conceptual in nature and highlights the importance of green marketing in the context of Indian market. It also highlights the opportunities and threats present in adopting green marketing strategies in the business.

\section{Firms adopting green marketing in India - case studies}

In this era of modernization green marketing achieve the reputation as an important concept in India. Enterprises such as HCL, TATA, MARUTI, ITC are renovating themselves as green. Green initiatives adopted by some renown companies in India:

1. Green IT Project @SBI - SBI is one of the great examples in banking sector in India. The bank installed eco-friendly power equipment's in app. 10,000atm's, saving operating costs and reduces the carbon footprints. SBI provides many services under the campaign of "Green Channel Counter" like paper less banking as no slip at the time of depositing and withdrawing money. SBI becomes the first Indian bank to installed 15megawatt wind farm to utilize the wind energy.

2. Kansai Nerolac (Lead Free Paint) - Kansai Nerolac is in the paint manufacturing business for more than 88years and it is the second largest company in India. Kansai is always working for the welfare of the society and environment, taking various initiatives in the area of education, health, sustainability, and community development. The company removed all the hazardous elements from their paint- Lead is the most prominent 
metal among all, which can cause adverse effect on human reproduction, kidney failure and nervous system. Now the entire range of home decorative are lead free.

3. India's First Green Statdium - Thyagaraj stadium is the first stadium of India to be awarded as green. It was built for hosting commonwealth games in 2010.stadium is awarded by (IGBC) Indian Green Building Council as gold rating. The stadium is built with the ecofriendly benchmarks such as solar system, gas generating system, rain water harvesting, use of waste waters in flush, effluent treatment etc.

4. Green Peripheral @ Wipro - Wipro infotech is the first IT company of India that launches an entire new range of ecofriendly laptops and desktops known as "Wipro Green Ware". These products are designed to reduce the e-waste as these are restricted of hazardous substances (ROHS).

5. DMRC (Delhi Metro Rail Corporation) - DMRC is the $13^{\text {th }}$ largest metro rail in the world (in terms of length), serving in the NCR region (Delhi, Faridabad, Ghaziabad, Gurugram, Noida) of India. According to a research by Central Road Research Institute (CRRI) DMRC helped in saving app. 33,000 tons of fuel and helps in prohibiting of emission of hazardous gases of 2,275 tons (M.K Sharma 2015). Delhi metro is working in an ecofriendly manner and creating an impact on the lives of people in NCR.

6. Campaign of Polythene free Himachal Pradesh - In the year 2009 on $2^{\text {nd }}$ oct the government of Himachal Pradesh puts a ban on the usage of polythene bags and its production and distribution. Many campaigns were held to highlight the hazardous impact of nonbiodegradable polythene bags and an appeal is made to the citizens and to the travelers to abandon the use of polyethene bags. Himachal government also won the prestigious award for excellence in public administration by prime minister.

7. IRCTC (Indian Railway Catering and Tourism Corporation) - IRCTC is working toward the aim of 'Going Paperless' while travelling through Indian railways making travelling ecofriendly. Travelers need not to carry printed version of tickets, they can carry their e-tickets with PNR no. in their mobiles and laptops. These initiatives help in saving costs keeping the personal information of customers safe and secure and helpful in environment protection.

8. NTPC Limited (Flyash Bricks) - NTPC limited generated 610.32 lakh tones of fly ashes during the year 2018-19 and $63.71 \%$ of fly ashes (388.81 lakh tons) of ashes had been utilized for different productive purposes. (Annual report of NTPC). NTPC is taking various ecofriendly initiatives for ash utilization as fly ash bricks, mines filling, development of land, RMC (ready mix concrete). The annual report of NTPC shows that
4.54 crore ash bricks were produced during the year 2018-19.

9. HUL (Hindustan Unilever Limited) - HUL is working with the vision of sustainability and believes that the decision we made today will put an impact on our environment and climate. Company is primarily working on the sustainable sourcing of agricultural raw material which includes sustainable fruits and vegetables, sustainable coffee, sustainable paper and board, sustainable tea, sustainable palm oils etc. HUL is also working in the area of waste management with the motive of 'Zero non-hazardous Waste to Landfill' at all the sites. According to sustainability report of HUL the factory waste generated by company were minimized by $63 \%$ in 2019 as compared to 2018, company implemented 3R's policy in all their offices and factories to promote the vision of sustainability.

\section{Conclusion}

With the adverse effect of organizations on environment causing global warming, Green marketing becomes an important tool for all the organizations to minimizing the environmental impact. Green marketing is not the matter of choice, (M.K Sharma 2015) it is the matter of need of an hour. Green marketing can be viewed as a new opportunity in today's competitive environment at global level. Green marketing is gaining the position of prominence in the developing countries like India where the basic problem is of 'choice' as resources are scarce and having unlimited human wants. Therefore, becomes the responsibility of the marketer to utilize the resources in an optimum manner without compromising the future. There is a need of green marketing in the economy to bring the shift in the attitude and buying behavior of consumers towards eco-friendly products and lifestyles (Sehgal 2017). Earlier the companies were taking ecofriendly measures under the pressure of government and legislations but now the scenario has changed, as more and more consumers aware throughout the globe and willing to adapt green products and services. A survey conducted by national geographic society in 2008 on consumer choice and environment. The study examined the current behavior of consumers on environment in 14 countries (India, Mexico, Canada, Russia, China, UK, France, US, and Germany). The study reported that the consumers in all the countries are becoming more concerned about the environmental issues and taking measures to control and reduce the wastage and consumption in their daily lives (Twinkle K Antony 2016). However green marketing is a new notion in the Indian market (Priya, Veena 2014) consumers are ready to pay premium cost for green products. Organizations are trying to perform ecofriendly through green production (ex. ITC limited), green packaging (ex. HUL less packaging), recycling (ex. coca cola) helps in cutting down the operating costs and wastage and turning into green operations. Companies also started educating their employees and society (ex. Surf Excel "Do Bucket Paani Roz Bachana", Maruti Suzuki provides green training to employees) to put 
an emphasis on the importance of green products and services. Green marketing is still a challenging concept in the Indian market, which requires innovative solutions so that green products and services can fetch a large area of market at global level. It is difficult for organizations to bear the responsibility of sustainability alone (Pooja 2016). Green marketing requires the active contribution from government as well as from the society. Green marketing requires that consumer will pay premium cost for green products and government should implement the regulations.

\section{Source of Funding}

None.

\section{Conflicts of Interest}

None.

\section{References}

1. B. Sangeetha, "Green Marketing - A Study on Green Products Intention of Consumers", J Business Manag Soc Sci Res. 2015

2. Chan ES. "Managing Green Marketing: Hong Kong hotel managers perspective", Int J Hospitality Manag. 2013; 34:442-61.

3. John C, SW, Abirami S. "Green as emerging color as a solution for an environment”, Int J Manag. 2015; 6(1):12735 .

4. Goshal M. "Green marketing - A changing concept in the changing time", BVIMR Manag Edge, 2011;4(1):82-92.

5. Jayadatta S, Ahmed SM. "Emerging trends, opportunity, challenges and creating awareness for green marketing in India”, Int J Business Manag Res. 2017;7(4):73-84.

6. Keller, Jha K. "Marketing Management", 13th Edition, Pearson Prentice Hall Publication.

7. Daniel MC, SW, Rylander DH "Strategic green marketing", The J Consumer Marketing.1993;10(3):4-10.

8. Narula S, Sabrawal D. "The theoretical study of green marketing in India: its importance and need", $J$ Mass Commun Journalism. S2:007, doi:10.4172/2165-7912.S2007:2-5(2016).

9. Nirala A, Chaudhary N. "Green marketing: A step towards sustainable growth”, Int J M Sci Technol. 2014;5(4)65-73.

10. Ottman JA, Stafford ER, Hartman CL. "Avoiding green myopia: Ways to improve consumer appeal for environmentally preferable products", Environ. 2006;48(5)22-36.

11. Panda LK, Goswami S. "Eco labels and its environment countenance", Orrisa Rev.2009;1-8.

12. Polonsky, M.J. (1994), "An introduction to green marketing”, Electronic Green Journal, vol. 1, no. 2.

13. Polonsky MJ, Rosenberger PJ. "Reevaluating green marketing: A strategic approach", Business Horizon. 2001;44(5):21-30.

14. Priya, Veena "Green marketing: Challenges \& strategy in the changing scenario", Int Res J Manag Sci Technol. 2014;5(10):50-2.

15. Ravi P, Beloor V. "Green marketing", Int J Eng Res Adv Technol. 2016;2(1):244-78.

16. Seghal P. "Green marketing: A tool for sustainable competitive advantage", Int J Commerce Art Sci. 2017; 8(3):56-66.

17. Singh S, Vrontis D, Thrassou A. "Green marketing and consumer behaviour: The case of gasoline products", $J$ Transnational Manag. 2011;16(2):84-106.

18. Sharma MK, Pandey N, Sajid R. "Green marketing: A study of emerging opportunity and challenges in Indian scenario", Int J of New Technol Res.2015;1(4):51-7.

19. Sharma NK, Kushwaha GS. "Ecolabels - A tool for green marketing or just a blind mirror for consumer", Electron Green J. 2019;1(42) ISSN:1076-7975.

20. Tiwari S, Tripathi DM, Srivastava U, Yadav PK, "Green marketing - Emerging dimensions", J Business Excellence. 2011;2(1)18-23.

21. Yadav, Rambalak, Pathak GS. ("Green Marketing: Initiatives in the Indian Context." Indian J of Marketing. 2013;43(10):25-32.

22. Yazdanifard R, Mercy IE. "The impact of green marketing on customers satisfaction and environment safety, Int Conf Computer Commun Manag. 2011;5:637-41.

23. Yengfui W, Yazdanifard R." "Green marketing: A study of consumers buying behavior in relation to green products", Glob J Manag Business Res.2015;15(5):17-23.

24. www.greenmarketing.net/stratergic.html.

25. www.theglobal-journals.com.

How to cite: Yadav A, Sharma U. Green marketing - A Theoretical study of opportunities and threats in the context of Indian market. J Manag Res Anal. 2020;7(3):122-6. 